\title{
WSPÓŁCZESNA RODZINA JAKO ŚRODOWISKO ŻYCIA I AKTYWNOŚCl OSÓB STARSZYCH. WYBRANE KWESTIE
}

DOI: http://dx.doi.org/10.12775/TiCz.2017.055

\section{WSTĘP}

Rodzina stanowi naturalne środowisko życia ${ }^{1}$ dla wszystkich jej członków, bez względu na ich wiek. W okresie późnej dorosłości ${ }^{2}$ wzrasta jej znaczenie, co wynika m.in. z faktu wycofywania się człowieka z szerszych kręgów społecznych. Rodzina odgrywa więc ważną rolę w życiu

* Dr Tomasz Różański jest adiunktem w Katedrze Socjologii Edukacji i Pedagogiki Społecznej Wydziału Nauk Pedagogicznych UMK w Toruniu (tomrozan@wp.pl).

${ }^{1}$ Przez pojęcie „środowisko życia” rozumie się w pedagogice „ogół warunków lub zasobów (...), w których jednostka żyje (doświadcza ich), organizowanych celowo lub występujących w sposób naturalny, posiadających znaczenie wychowawcze (wpływających na jednostkę i wyznaczających jej rozwój w określonym kierunku), oddziałujących w sposób bezpośredni (osobista styczność) lub pośredni (styczność symboliczna), różniących się siłą oddziaływania (silniejszy bądź słabszy wpływ rozwojowy). Ważny jest przy tym relacyjny aspekt funkcjonowania jednostki w środowisku jej życia". E. Wysocka, Człowiek a środowisko życia. Podstawy teoretyczno-metodologiczne diagnozy, Warszawa 2006, s. 21.

${ }^{2}$ Por. M. Straś-Romanowska, Późna dorostość. Wiek starzenia się, w: Psychologia rozwoju człowieka. Charakterystyka okresów życia człowieka, red. B. Harwas-Napierała, J. Trempała, Warszawa 2005, s. 263-292. 
seniorów, stanowi dla nich najistotniejsze środowisko życiowej aktywności oraz podstawową grupę odniesienia. Funkcjonująca w prawidłowy sposób rodzina jest dla osób starszych głównym źródłem wsparcia w rozmaitych obszarach życia ${ }^{3}$. Ułatwia im również przystosowanie się do okresu starości oraz związanych z nim przeobrażeń. Opierając się na rodzinie, seniorzy zwykle dłużej pozostają samodzielni i niezależni - wolni od innych, zwłaszcza instytucjonalnych form wsparcia społecznego ${ }^{4}$. Dokonujące się współcześnie zmiany społeczno-kulturowe przyczyniają się jednak do obniżania pozycji ludzi starszych w życiu rodzinnym i społecznym ${ }^{5}$. Istotnym problemem dla wielu seniorów są coraz rzadsze ich „kontakty z dziećmi i wnukami opuszczającymi środowisko lokalne w poszukiwaniu pracy i w celu zdobycia wykształcenia (...). Osłabione kontakty i więzi emocjonalne $\mathrm{z}$ bliskimi skutkują poczuciem osamotnienia, (...) izolacji,

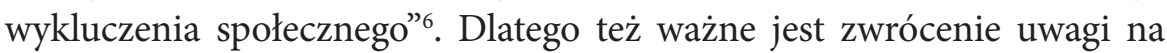
współpracę między pokoleniami, przede wszystkim w rodzinie ${ }^{7}$.

Niniejszy artykuł poświęcono wybranym kwestiom dotyczącym współczesnej rodziny jako środowiska życia i aktywności ludzi starszych. Poruszono w nim takie zagadnienia, jak: pojęcie, struktura i funkcje rodziny; fazy życia rodzinnego osób starszych; rola rodziny w zaspokajaniu potrzeb seniorów; aktywność ludzi starszych oraz role pełnione przez nich w środowisku rodzinnym.

\section{RODZINA - JEJ ISTOTA, STRUKTURA I FUNKCJE}

Pojęcie rodziny jest w różny sposób definiowane w literaturze naukowej. Terminem tym określa się najczęściej:

3 A. Leszczyńska-Rejchert, Człowiek starszy i jego wspomaganie - $w$ stronę pedagogiki starości, Olsztyn 2010, s. 89.

4 A. Chabior, Życie rodzinne i funkcjonowanie gospodarstwa domowego, w: Ludzka starość. Wybrane zagadnienia gerontologii społecznej, A. Fabiś, J.K. Wawrzyniak, A. Chabior, Kraków 2015, s. 135.

${ }^{5}$ Por. K. Segiet, Miejsce człowieka starego w codzienności rodzinnej, w: Starość w perspektywie studiów pedagogicznych, red. A. Tokaj, Leszno 2008, s. 59-60.

${ }^{6}$ E. Trafiałek, Wykluczenie społeczne ludzi starszych. Źródła, skutki, perspektywy na przyszłość, w: Starość i starzenie się jako doświadczenie jednostek i zbiorowości ludzkich, red. J.T. Kowaleski, P. Szukalski, Łódź 2006, s. 172-173.

7 Por. S. Steuden, Psychologia starzenia się i starości, Warszawa 2011, s. 130. 
- podstawową grupę społeczną złożoną zwykle z jednego bądź dwojga rodziców i ich potomstwa;

- dwoje bądź więcej osób, jakie pozostają w długotrwałym związku, dzielą to samo miejsce zamieszkania oraz mają wspólne cele i wartości;

- grupę osób związanych krwią bądź małżeństwem;

- ród (pochodzenie);

- członków tego samego gospodarstwa domowego, którzy zamieszkują pod jednym dachem;

- grupę ludzi, którzy mają wspólnych przodków ${ }^{8}$.

Zdaniem Leona Dyczewskiego, rodzina to mała grupa o charakterze wspólnotowym oraz instytucja społeczna opierająca się „na miłości i wolnym wyborze kobiety i mężczyzny połączonych małżeństwem, którzy odpowiadając wzajemnie za siebie, rodzą i wychowują następne pokolenie w taki sposób, aby ono także rodziło i wychowywało nowe pokolenie" 9 .

Według innego badacza - Franciszka Adamskiego, „rodzina stanowi duchowe zjednoczenie szczupłego grona osób, skupionych we wspólnym ognisku domowym aktami wzajemnej pomocy i opieki, oparte na wierze w prawdziwą lub domniemaną łączność biologiczną, tradycję rodzinną i społeczną"10. Wyróżniają ją takie elementy, jak: wspólne zamieszkanie jej członków, wspólna własność, nazwisko, ciągłość biologiczna, wspólna kultura duchowa ${ }^{11}$.

Charles H. Cooley uznaje rodzinę za grupę pierwotną, którą cechuje współpraca oraz bezpośredni kontakt wchodzących w jej skład osobników. Członków rodziny łączą silne więzi społeczne, a ich kontakty mają charakter częstych, bliskich i intymnych. Grupy pierwotne obejmują niewielką liczbę osób, w przeciwieństwie do grup wtórnych, większych pod względem liczby członków oraz opartych na stosunkach formalnych ${ }^{12}$. Stanowiąc małą grupę pierwotną, rodzina zachowuje jednak swój swoisty charakter. Tym, co odróżnia ją od typowej małej grupy, jest w szczegól-

8 T. Biernat, O przemianach definiowania rodziny $i$ ich konsekwencjach, „Społeczeństwo i Rodzina” 18 (2009) 1, s. 29-30.

9 L. Dyczewski, Rodzina, społeczeństwo, państwo, Lublin 1994, s. 27.

10 F. Adamski, Rodzina. Wymiar społeczno-kulturowy, Kraków 2002, s. 29.

11 Tamże.

12 Tamże. 
ności: „sposób wchodzenia do niej nowych członków, zanik przywództwa typowego dla małej grupy, wyraźny podział pokoleniowy oraz intymność stosunków"13.

Jak już zauważono, rodzina jest grupą pierwotną, jednakże społeczeństwo stawia jej rozmaite formalne wymagania ${ }^{14}$. Stąd rodzina może być rozpatrywana także jako instytucja społeczna. Takie jej rozumienie wiąże się z uwzględnianiem różnorakich cech i funkcji oraz swoistego układu stosunków pomiędzy osobnikami różnej płci i wieku ${ }^{15}$. Jak podaje F. Adamski: „Układ ten wyznacza normy regulujące współżycie seksualne, wydawanie na świat dzieci i ich wychowanie, a także linie pokrewieństwa, dziedziczenia majątku i współdziałanie w ramach gospodarstwa domowego"16. Ujmowanie rodziny jako instytucji społecznej uwzględnia jej formalne ustanowienie i funkcjonowanie wedle przyjętych norm społecznych w ramach określonego systemu kontroli społecznej. Rodzina jako instytucja jest przede wszystkim przedmiotem rozważań, które odnoszą się do jej struktury, zakresu działania, ról jej członków, a także spełnianych przez nią funkcji. Sens tak rozumianej rodziny sprowadza się głównie do pełnienia przez nią funkcji istotnych dla rozwoju społeczeństwa ${ }^{17}$.

W następstwie dokonujących się współcześnie dynamicznych zmian społecznych i kulturowych pojawia się coraz więcej definicji rodziny uwzględniających tzw. alternatywne formy życia małżeńsko-rodzinnego $^{18}$ (np. związki kohabitacyjne). Jak utrzymuje Tomasz Biernat, ten sposób rozumienia rodziny prowadzi do zacierania prawdy o jej naturze i powołaniu. W konsekwencji przyczynia się do zmiany jej tożsamości ${ }^{19}$.

${ }^{13}$ F. Adamski, Socjologia małżeństwa i rodziny. Wprowadzenie, Warszawa 1984, s. 24 .

14 Z. Tyszka, Struktura i funkcje rodziny oraz świadomość rodzinna, w: Podstawowe pojęcia i zagadnienia socjologii rodziny, Z. Tyszka, A. Wachowiak, Poznań 1997, s. 43.

15 F. Adamski, Rodzina, w: Encyklopedia pedagogiczna XXI wieku, t. 5, red. T. Pilch, Warszawa 2006, s. 306.

16 Tamże.

17 F. Adamski, Socjologia małżeństwa i rodziny, s. 22.

18 Por. K. Slany, Alternatywne formy życia małżésko-rodzinnego w ponowoczesnym świecie, Kraków 2002; W. Bołoz, Przemiany rodziny we współczesnym społeczeństwie, „Homo Dei” 78 (2009) 1, s. 11-21.

19 T. Biernat, dz. cyt., s. 36 . 
Rodzina, podobnie jak inne grupy społeczne, posiada swoją strukturę, tzn. układ ogółu elementów i zasad ich wzajemnego podporządkowania, pozwalający na funkcjonowanie grupy ${ }^{20}$. Wśród elementów określających strukturę rodziny wyróżnia się: liczbę i rodzaj pokrewieństwa osób wchodzących w skład rodziny; układ ich pozycji i ról społecznych; ich usytuowanie przestrzenne; siłę więzi instytucjonalnych i psychicznych, które łączą poszczególnych członków rodziny; podział czynności oraz strukturę władzy i autorytetów; wewnątrzrodzinny rozkład miłości i względów ${ }^{21}$.

Do składników struktury rodziny zalicza się więź rodzinną ${ }^{22}$. Stanowi ona „wypadkową wewnętrznych i zewnętrznych sił istniejących w grupie rodzinnej i działających na jej członków. Siły te splatają poszczególne jednostki w jedną strukturalną i wieloelementową całość" ${ }^{23}$. Więź rodzinna wyraża się $\mathrm{w}$ różnego rodzaju relacjach, zależnościach oraz postawach członków rodziny. Z drugiej strony różnego typu postawy, stosunki i zależności członków rodziny są fundamentem jej istnienia oraz rozwoju. Więź rodzinna to zjawisko dynamiczne, podlegające stałym przeobrażeniom $^{24}$.

Ze strukturą rodziny ściśle związane są jej funkcje. Są one zdeterminowane przez elementy struktury, same również oddziałują na strukturę rodziny, charakter więzi, jakie łączą jej członków ${ }^{25}$. Zdaniem Władysława Majkowskiego, funkcje rodziny oznaczają role, jakie rodzina spełnia w stosunku do społeczeństwa oraz samych członków rodziny, a także cele i zadania, do jakich zmierzają działania rodzinne oraz życie rodziny ${ }^{26}$.

20 A. Kwak, Rodzina jako środowisko wychowawcze, w: Pedagogika społeczna. Człowiek w zmieniającym się świecie, red. T. Pilch, I. Lepalczyk, Warszawa 1993, s. 123.

${ }^{21}$ Z. Tyszka, Z metodologii badań socjologicznych nad rodzina, Poznań 1991, s. 60.

${ }^{22}$ A. Kwak, Rodzina - formy $i$ warunki funkcjonowania, w: Encyklopedia pedagogiczna XXI wieku, t. 5, red. T. Pilch, Warszawa 2006, s. 312.

${ }^{23}$ L. Dyczewski, Rodzina, społeczeństwo, s. 21.

${ }^{24}$ Tamże.

25 Z. Tyszka, Z metodologii badań, s. 61.

${ }^{26}$ W. Majkowski, Funkcje, w: Słownik małżeństwa i rodziny, red. E. Ozorowski, Warszawa-Łomianki 1999, s. 391. 
W literaturze naukowej proponuje się rozmaite klasyfikacje funkcji rodziny $^{27}$. Różnią się one między sobą np. liczbą wyróżnionych funkcji, zasadami podziału, terminologią ${ }^{28}$. Jedną z takich klasyfikacji stworzył Franciszek Adamski ${ }^{29}$. Wyróżnił on funkcje rodziny ze względu na: analizę rodziny jako grupy i instytucji społecznej oraz problem trwałości i zmienności jej funkcji.

Uwzględniając pierwsze kryterium, uczony wydzielił dwie grupy funkcji: instytucjonalne i osobowe. Do funkcji instytucjonalnych zaliczył te, które odnoszą się do rodziny jako instytucji społecznej. Należą do nich funkcje: prokreacyjna bądź biologiczna (jej wypełnianie prowadzi do podtrzymywania ciągłości społeczeństwa); ekonomiczna (służy dostarczaniu materialnych dóbr rodzinie); opiekuńcza (polega na zabezpieczeniu członków rodziny w sytuacjach, kiedy nie są oni w stanie samodzielnie zaspokoić swoich potrzeb); socjalizacyjna (realizowana jest przez wprowadzanie członków rodziny w życie społeczne oraz zaznajamianie ich z wartościami kultury); stratyfikacyjna (polega na zagwarantowaniu członkom rodziny określonego statusu życiowego, określa ich przynależność do danej warstwy społecznej); integracyjna (stanowi funkcję społecznej kontroli zachowań członków rodziny). Funkcje osobowe odnoszą się natomiast do rodziny jako grupy społecznej. Wśród nich autor wyodrębnił funkcje: małżeńską (służącą realizacji potrzeb życia intymnego małżonków); rodzicielską (polegającą na zaspokajaniu potrzeb uczuciowych rodziców i dzieci) i braterską (wypełnianą poprzez realizację potrzeb uczuciowych braci i sióstr).

Funkcje rodziny rozpatrywane z perspektywy ich trwałości i zmienności F. Adamski podzielił na dwie grupy. Po pierwsze, wyróżnił funkcje istotne (pierwszorzędne), uznając je za niezbywalne. Należą do nich funkcje: prokreacyjna, socjalizacyjna oraz funkcja miłości. Po drugie, wskazał na funkcje akcydentalne (drugorzędne), tzn. te, bez realizacji których

27 Socjologowie wyróżniają zazwyczaj następujące funkcje rodziny: reprodukcyjną, socjalizacyjną, opiekuńczą, emocjonalną, seksualną, ekonomiczną, stratyfikacyjną, identyfikacyjną, rekreacyjno-towarzyską i integracyjno-kontrolną. T. Szlendak, Socjologia rodziny. Ewolucja, historia, zróżnicowanie, Warszawa 2010, s. 116-117.

${ }_{28}$ M. Dudek, Funkcje rodziny, w: Leksykon pedagogiki rodziny, red. J. Kułaczkowski, Warszawa 2011, s. 58.

${ }^{29}$ F. Adamski, Rodzina. Wymiar społeczno-kulturowy, s. 36-37. 
rodzina może funkcjonować bez znacznej dla siebie i dla społeczeństwa szkody. Do nich zaliczył funkcje: ekonomiczną, stratyfikacyjną, opiekuńczą, rekreacyjną, religijną (stanowiącą część funkcji socjalizacyjnej) i integracyjną, której jednak nie można uznać za całkowicie zbywalną, ponieważ jej elementy zawierają się w funkcji socjalizacyjnej oraz funkcji miłości.

Bez względu na liczbę uwzględnianych funkcji oraz sposobów ich hierarchizowania, do naczelnych zadań rodziny należy utrzymywanie ciągłości biologicznej i kulturowej społeczeństwa, a także realizacja fundamentalnych potrzeb emocjonalnych i bezpieczeństwa. Rodzina spełnia także funkcje kontrolne w stosunku do swych członków oraz funkcje gospodarcze i zabezpieczające ${ }^{30}$.

\section{MIEJSCE 1 ROLA CZŁOWIEKA STARSZEGO WE WSPÓŁCZESNEJ RODZINIE - WYBRANE ZAGADNIENIA}

Współczesne przemiany społeczno-kulturowe przyczyniły się do istotnych przeobrażeń zarówno w obrębie struktury rodziny, jak i w zakresie jej funkcjonowania ${ }^{31}$. Jak podaje Zofia Szarota: „Upowszechnił się model rodziny nuklearnej, znaczna część osób starszych nie mieszka ze swoimi dziećmi, prowadząc, w wyniku np. wdowieństwa, jednoosobowe gospodarstwa" ${ }^{2}$. Obserwuje się również wyraźne zachwianie pozycji ludzi starych w życiu społecznym i rodzinnym. Przyczyn tego stanu rzeczy należy doszukiwać się przede wszystkim w wydłużającym się życiu człowieka (wywołanym rozwojem medycyny oraz zwiększeniem stopy życiowej), a także we wzrastającym tempie dokonujących się zmian na świecie oraz silnym zwróceniu się jednostek i społeczeństw ku przyszłości. Dynamiczne zmiany pociągnęły za sobą kult postępu. Takie cechy jak spryt, zaradność czy umiejętność podejmowania ryzyka znajdują coraz

30 A. Kwak, Rodzina jako środowisko, s. 131.

31 Por. T. Różański, Z problematyki przemian i zagrożeń współczesnej rodziny, „Teologia i Człowiek” 32 (2015) 4, s. 129-141.

${ }^{32}$ Z. Szarota, Starzenie się $i$ starość $w$ wymiarze instytucjonalnego wsparcia na przykładzie Krakowa, Kraków 2010, s. 109. 
większe uznanie, często większe aniżeli mądrość życiowa i doświadczenie. To przyczynia się do pozostawiania osób starszych na uboczu ${ }^{33}$.

Rodziny tworzone przez ludzi w starszym wieku zwykle znajdują się w fazie pustego gniazda, która dotyczy okresu małżeństwa po usamodzielnieniu się dzieci i opuszczeniu przez nie domu rodzinnego. Momentem wieńczącym ten etap jest zazwyczaj śmierć jednego ze współmałżonków. Faza pustego gniazda coraz częściej ulega wydłużeniu w wyniku wzrostu trwania życia człowieka. Wiele osób starszych mieszka jednak wspólnie ze swymi dorosłymi dziećmi, które nierzadko nie są w stanie zaspokoić swoich potrzeb życiowych ${ }^{34}$. Zdarza się, że „wspólne zamieszkiwanie seniorów i ich (...) dzieci może prowadzić do sytuacji trudnych, niosących za sobą ryzyko konfliktów i nieporozumień. Taka sytuacja określana jest mianem przepełnionego gniazda i jest wynikiem niemożności nabycia przez dzieci własnego lokalu mieszkaniowego. (...) bardzo trudne jest ustalenie granicy między sytuacją przymusową, jaką jest faza przepełnionego gniazda, a własną wolą i chęcią kontynuowania modelu wielopokoleniowej rodziny nader często przejawianą przez starzejących się rodziców”35.

Biorąc pod uwagę fazy życia rodzinnego ludzi starszych, można wyodrębnić następujące schematy ich przebiegu:

- faza odejścia dorastających dzieci z domu rodzinnego - puste gniazdo - wdowieństwo i etap samotnego zamieszkiwania;

- faza odejścia dorastających dzieci z domu rodzinnego - puste gniazdo - wdowieństwo i etap samotnego zamieszkiwania - faza rekohabitacji;

- faza odejścia dorastających dzieci z domu rodzinnego/wdowieństwo - ponowne małżeństwo - wdowieństwo;

- etap opuszczenia domu rodzinnego przez część dorastających dzieci - przepełnione gniazdo bądź pozostawanie w rodzinie wielopokoleniowej - wdowieństwo/dalsze zamieszkiwanie z własnym potomstwem ${ }^{36}$.

33 S. Smoląg, Funkcjonowanie starszych pokoleń $w$ życiu rodzinnym i społecznym, w: Oblicza starości we współczesnym świecie. Perspektywa społeczno-kulturowa, t. 2, red. M. Guzewicz, S. Steuden, P. Brudek, Lublin 2015, s. 91.

34 A. Chabior, dz. cyt., s. 136-137.

35 Tamże, s. 137.

${ }^{36}$ B. Szatur-Jaworska, Życie rodzinne ludzi starych w Polsce, „Polityka Społeczna” 26 (1999) 9, s. 19. 
Barbara Szatur-Jaworska stwierdza, że:

Zarówno w przypadku wspólnego, jak i osobnego zamieszkiwania, między starszymi rodzicami i dorosłymi dziećmi dokonuje się wzajemna wymiana świadczeń i usług. W początkowej fazie starości ludzie starsi więcej dają niż biorą, gdyż mają i siły, i środki, by pomagać dorosłym dzieciom oraz zajmować się wnukami. W miarę, jak starzeją się i coraz częściej chorują, a ich wnuki dorastają, ludzie starzy świadczą rodzinie pomoc mniejszą niż ta, którą od niej otrzymują. W tym okresie rodzina rewanżuje się sędziwym rodzicom pomagając $\mathrm{w}$ razie choroby i niepełnosprawności ${ }^{37}$.

Jak wynika z badań, pomoc ta obejmuje również robienie zakupów, wykonywanie prac domowych, załatwianie spraw w różnych instytucjach i in. ${ }^{38}$ Osoby starsze w Polsce najczęściej mieszkają w pojedynkę, jednakże w pobliżu swoich dzieci, dzięki temu mogą liczyć na ich wsparcie. Pragną zachować jak najdłużej samodzielność, a równocześnie mieć blisko siebie tych, na których mogą polegać39.

Należy ponadto zauważyć, że rodzina spełnia w życiu seniorów istotną funkcję ekspresyjną, a także przyczynia się do wzmacniania ich społecznego uczestnictwa. To wspólnie z nią organizowane są rozmaite uroczystości, np. urodziny, imieniny, obchody świąt kościelnych. W rodzinie osoby starsze mają możliwość utrzymywania bliskich i częstych kontaktów z przedstawicielami młodszych pokoleń. Tam tworzy się więź międzypokoleniowa ${ }^{40}$.

Dla seniorów, którzy zwykle nie są już czynni zawodowo, rodzina stanowi podstawowe miejsce realizacji codziennej aktywności ${ }^{41}$. Ich aktywność

37 Tamże, s. 17.

38 P. Czekanowski, Rodzina $w \dot{z} y c i u$ osób starszych $i$ osoby starsze $w$ rodzinie, w: Polska starość, red. B. Synak, Gdańsk 2002, s. 172.

39 A. Chabior, dz. cyt., s. 139.

40 B. Szatur-Jaworska, dz. cyt., s. 17.

${ }^{41} \mathrm{Z}$ przeprowadzonych w ostatnich latach badań i analiz wynika, że codzienna aktywność polskich seniorów (również wolnoczasowa) koncentruje się przede wszystkim wokół spraw rodzinnych i domowych. Por. M. Brzezińska, Proaktywna starość. Strategie radzenia sobie ze stresem w okresie późnej dorosłości, Warszawa 2011, s. 64; E. Trafiałek, Starość w Polsce, w: Zagrożenia człowieka i idei sprawiedliwości społecznej, t. 1, red. T. Pilch, T. Sosnowski, Warszawa 2013, s. 198-199; M. Zrałek, Społeczne konteksty 
ekonomiczna podejmowana jest przede wszystkim w obrębie gospodarstwa domowego ${ }^{42}$. Wykonując rozmaite czynności na rzecz innych członków rodziny (m.in. opieka, pomoc), osoba starsza zaspokaja wiele ważnych potrzeb, np. użyteczności, prestiżu, bezpieczeństwa. Seniorzy nie powinni jednak koncentrować się wyłącznie na aktywności domowo-rodzinnej, powinni mieć również czas na życie duchowe, towarzyskie oraz realizację ulubionych czynności (także tych, które nie są związane z życiem rodzinnym) ${ }^{43}$.

Ewa Miszczak podaje, że „rodzina jest pełna wtedy, gdy funkcjonują w jej ramach przedstawiciele wszystkich trzech pokoleń, stanowiących reprezentację naturalnych faz życia człowieka. Bliski, nacechowany emocjonalnie kontakt $\mathrm{z}$ osobami $\mathrm{w}$ różnym wieku, sprzyja osobistemu zapoznawaniu się z rzeczywistymi problemami i zagadnieniami występującymi w kolejnych etapach egzystencji danej jednostki"4. Seniorzy pełnią $\mathrm{w}$ rodzinie ważną funkcję przekazicieli wiedzy historycznej, kultury, tradycji. Dziadkowie są często ogniwem pośredniczącym między rodzicami a dziećmi. Niekiedy pełnią funkcję mediatorów w rozmaitych sytuacjach problemowych. Najbardziej aktywni w zakresie pełnienia swych funkcji rodzinnych są zazwyczaj młodsi seniorzy. Wykazują często jeszcze wysoki poziom sprawności fizycznej i psychicznej, przejawiają większe zainteresowanie otaczającym światem. W miarę postępującego procesu starzenia się i towarzyszących mu przemian zaznacza się tendencja do stopniowego wycofywania się człowieka z szerszych kręgów społecznych ${ }^{45}$.

Osoby starsze, przechodząc na emeryturę, nierzadko są już babciami lub dziadkami. Uczestniczą w wielu istotnych dla rodziny sytuacjach ${ }^{46}$. Trudno przecenić ich udział w procesie wychowania młodego pokolenia. Jak utrzymuje Małgorzata Dzięgielewska, „w polskich rodzinach babcie

starzenia się w Polsce, w: Starość w Polsce. Aspekty społeczne i edukacyjne, A. Fabiś, M. Muszyński, Ł. Tomczyk, M. Zrałek, Oświęcim 2014, s. 34.

${ }^{42}$ B. Szatur-Jaworska, dz. cyt., s. 17.

43 G. Orzechowska, Aktualne problemy gerontologii społecznej, Olsztyn 1999, s. $31-32$.

${ }^{44}$ E. Miszczak, Funkcjonowanie rodziny $z$ osoba $w$ wieku sędziwym, w: Rodzina polska. Wybrane aspekty funkcjonowania, red. M. Szyszka, Lublin 2013, s. 87.

${ }^{45}$ Tamże, s. 87-88.

${ }^{46}$ M. Dzięgielewska, Człowiek stary a rodzina, w: Podstawy gerontologii społecznej, B. Szatur-Jaworska, P. Błędowski, M. Dzięgielewska, Warszawa 2006, s. 99. 
i dziadkowie wobec wnuków odgrywają rolę szczególną. Przekazują im zasady moralne, obyczaje i tradycje. Przekazują wartości przez nich uświęcone, kształtują tym samym postawy najmłodszych. Dla wnuków i swoich dzieci są oparciem w wymiarze duchowym. To dziadkowie są nauczycielami patriotyzmu i miłości Ojczyzny, przekazują tradycje rodzinne i narodowe. To oni stanowią pomost między dawnymi a nowymi laty, nawiązują łączność duchową z przodkami, z wartościami uświęconymi przez pokolenia. Dziadkowie chętnie opowiadają o wydarzeniach, których byli świadkami. W swych opowiadaniach przekazują wiedzę o uroczystościach rodzinnych i narodowych, o zabawach i przyjęciach, ale też o smutnych losach Polaków (...). Przekazują młodszemu pokoleniu historię rodzinną, często wiążąc ją z wydarzeniami w środowisku zamieszkania i wydarzeniami globalnymi" ${ }^{47}$.

Można stwierdzić zatem, że dziadkowie stoją na straży przekazu kulturowego (zwłaszcza tradycji, obyczajów ${ }^{48}$ ), jaki dokonuje się w rodzinie. Kształtują postawy najmłodszych jej członków wobec fundamentalnych wartości, rozbudzają ich zainteresowania, umożliwiają określenie tożsamości historycznej ${ }^{49}$. Nierzadko odgrywają też ważną rolę w wychowaniu religijnym wnuków ${ }^{50}$. Rola babci lub dziadka jest dla ludzi w starszym wieku jedną z najistotniejszych ról społecznych ${ }^{51}$ - umacnia poczucie ich własnej tożsamości. Stanowi ona swego rodzaju przedłużenie roli rodzicielskiej ${ }^{52}$. Jak zauważa Renata Konieczna-Woźniak: „Maleje jednak udział ludzi starszych w uczeniu młodszych, bo rozpad rodzin wielopoko-

47 Tamże, s. 103.

48 Por. L. Dyczewski, Rodzina twórca i przekazicielem kultury, Lublin 2003, s. 106.

${ }^{49}$ M. Dzięgielewska, dz. cyt., s. 103-104.

${ }^{50}$ Por. N. Pikuła, Etos starości w aspekcie społecznym. Gerontologia dla pracowników socjalnych, Kraków 2011, s. 104.

${ }^{51}$ Rolą społeczną określa się „zespół oczekiwań odnoszących się do zachowań osoby zajmującej daną pozycję w strukturze społecznej lub ogół praw i obowiązków wiążących się z daną pozycją społeczną lub stanowiskiem”. M. Pacholski, A. Słaboń, Słownik pojęć socjologicznych, Kraków 2010, s. 185. Por. W. Misiak, Rola społeczna, w: Elementarne pojęcia pedagogiki społecznej i pracy socjalnej, red. D. Lalak, T. Pilch, Warszawa 1999, s. 247-248.

52 A. Tokaj, Rodzina w życiu seniora a przebieg procesu jego adaptacji do starości, w: Seniorzy $w$ rodzinie, instytucji i społeczeństwie. Wybrane zagadnienia wspótczesnej gerontologii, red. A. Fabiś, Sosnowiec 2005, s. 44. 
leniowych osłabił rolę seniorów w przekazie międzypokoleniowym. Stan taki nie jest tylko zagrożeniem dla pozycji osób starszych, osłabieniem ich rangi w rodzinie. Sytuacja ta również budzi wielki niepokój o osoby młodsze. Oddzielenie pokoleniowe naraża bowiem człowieka na brak zakorzenienia we własnej tożsamości"53.

Z przeglądu badań dokonanego przez Małgorzatę Brzezińską ${ }^{54}$ wynika, że w obszarze relacji rodzinnych najistotniejszą rolę dla osób starszych odgrywają stosunki z ich dziećmi. Około 90\% badanych seniorów ma (bądź miało) dzieci (zwykle jedno lub dwoje). Prawie połowa respondentów zamieszkuje wspólnie z dziećmi (a więc znaczniej mniej niż jeszcze kilkadziesiąt lat temu). W sferze relacji seniorów z dziećmi (oraz innymi członkami rodziny) istotną rolę odgrywają więzi emocjonalne. Większość badanych uważa, że ich pozycja w rodzinie jest stabilna, a stosunki z jej członkami dobre. Występujące problemy rodzinne związane są głównie ze zmianami ról rodzinnych, przejściem jednego bądź obu współmałżonków na emeryturę, zbyt późnym odejściem z domu rodzinnego ostatniego bądź jedynego dziecka, a także z chorobą współmałżonka. W sferze kontaktów społecznych seniorów ważne miejsce zajmują więzi w ich wnukami. Z badań wynika, że kontakty te są częste, a wraz z upływającym czasem podlegają przemianom. Dziadkowie okazują się osobami ważnymi w życiu ich wnucząt, „są (...) nauczycielami praktycznych umiejętności, przewodnikami po świecie wartości, tradycji, kultury i cnót ważnych w codziennym życiu (...). Problem może stanowić nadmierna opiekuńczość dziadków i przejmowanie roli rodziców" ${ }^{55}$. Kontakty z wnukami przyczyniają się natomiast do zmniejszenia poczucia osamotnienia i bezużyteczności wśród seniorów, ponadto stymulują ich do podejmowania różnych form aktywności. Zarówno te, jak i niektóre $\mathrm{z}$ wcześniej przeprowadzonych analiz ${ }^{56}$, dają stosunkowo pozytywny obraz sytuacji rodzinnej osób starszych w Polsce.

${ }^{53}$ R. Konieczna-Woźniak, Zaangażowanie ludzi starszych $w$ przekaz międzypokoleniowy, w: Dorosłość wobec starości. Oczekiwania. Radości. Dylematy, red. R. Konieczna-Woźniak, Poznań 2008, s. 312.

${ }^{54}$ M. Brzezińska, dz. cyt., s. 48-49.

55 Tamże, s. 49.

${ }^{56}$ Por. E.M. Skibińska, Mikroświaty kobiet. Relacje autobiograficzne, Warszawa 2006, s. 314-316. 


\section{UWAGI KOŃCOWE}

Jak już podkreślano, rodzina stanowi naturalne środowisko życia dla wszystkich jej członków, bez względu na wiek. Szczególną rolę odgrywa ona w życiu ludzi starszych. Stanowi dla wielu z nich podstawową płaszczyznę egzystencji oraz główne środowisko życiowej aktywności. Również seniorzy odgrywają istotne role $\mathrm{w}$ rodzinie, m.in. pomagają jej członkom w różnych sytuacjach życiowych, spełniają ważne funkcje opiekuńcze i wychowawcze.

Dokonujące się we współczesnym świecie dynamiczne zmiany społeczne, kulturowe i ekonomiczne przyczyniają się w coraz większej mierze do obniżania pozycji osób starszych w rodzinie i społeczeństwie. To może prowadzić do ich marginalizacji w wielu sferach życia ${ }^{57}$. Dlatego też ważne jest stwarzanie różnorakich okazji do rodzinnych (i pozarodzinnych) spotkań międzypokoleniowych ${ }^{58}$, zwłaszcza takich, które pozwalają na współpracę, dzielenie się doświadczeniami oraz wspieranie się. Za istotne należy uznać „tworzenie rodzinom i przez nie same warunków sprzyjających psycho-społeczno-pedagogicznemu funkcjonowaniu. Wspomaganie powinno odbywać się zarówno w domu rodzinnym, jak i poza nim, w oparciu o sieć instytucji i usług, szeroką ofertę - od profilaktyki do kompensacji, skierowanych do rodzin"59. Działalność wspierająca stanowi jeden z komponentów integracji społecznej. Służy umacnianiu więzi międzyludzkich i kształtowaniu poczucia tożsamości ze środowiskiem lokalnym, ponadto przyczynia się do eliminowania źródeł i konsekwencji wykluczenia społecznego ${ }^{60}$.

Warto na koniec przywołać nadal aktualne, następujące słowa Leona Dyczewskiego: „Dawniej więź międzypokoleniowa bazowała na wspólnocie gospodarczej i domowej, dzisiaj pokolenia chcą ją oprzeć na

${ }^{57}$ Por. A. Chabior, J.K. Wawrzyniak, Marginalizacja i dyskryminacja osób w okresie późnej dorosłości, w: Ludzka starość. Wybrane zagadnienia gerontologii społecznej, A. Fabiś, J.K. Wawrzyniak, A. Chabior, Kraków 2015, s. 241-257.

${ }^{58}$ Por. J. Halicki, Relacje międzygeneracyjne jako jeden z elementów poszerzających przestrzeń życiowa ludzi starszych, w: Przestrzeń życiowa i społeczna ludzi starszych, red. M. Dzięgielewska, Łódź 2000, s. 275-280.

\footnotetext{
${ }^{59}$ K. Segiet, dz. cyt., s. 64.

${ }^{60}$ E. Trafiałek, Polska starość $w$ dobie przemian, Katowice 2003, s. 280.
} 
względnej niezależności materialnej, dobrowolności świadczeń i bliskości zamieszkiwania. Kształtujący się typ rodziny lokalizuje więc dziadków tuż obok rodziny, dzieci i wnuków: w tym samym bloku, osiedlu, na tej samej ulicy. Tendencję tę należy wziąć pod uwagę w budownictwie mieszkaniowym i w polityce mieszkaniowej. Tak należy urządzać nowoczesne osiedla i miasta, by stwarzały najbardziej naturalne warunki życia dla człowieka, który w rodzinie przychodzi na świat, w niej osiąga swój rozwój i w niej powinien przeżyć ostatnie lata"61.

Streszczenie. Niniejszy artykuł poświęcono wybranym problemom współczesnej rodziny jako środowiska życia i aktywności ludzi starszych. Punktem wyjścia podjętych rozważań było określenie pojęcia rodziny oraz scharakteryzowanie jej struktury i podstawowych funkcji. W dalszej kolejności zwrócono uwagę na fazy życia rodzinnego ludzi starszych oraz rolę rodziny w zaspokajaniu ich potrzeb. Nie pominięto zagadnienia aktywności seniorów oraz zasadniczych ról pełnionych przez nich w środowisku rodzinnym. Ponadto odwołano się do rezultatów wybranych badań dotyczących podjętej problematyki.

Słowa kluczowe: aktywność; rodzina; role rodzinne; senior; środowisko życia.

Abstract. Modern Family - The Environment of Living and Activity of the Elderly. Selected Issues. This article deals with selected problems of contemporary family as an environment of living and activity of the elderly. The starting point for the discussion was defining the concept of family and characterization of its structure and basic functions. Further, the attention was paid to the stages of older people's family life and to the role of family in satisfying their needs. The issue of seniors' activity and essential roles they play in family environment was not overlooked either. In addition, there are references to the results of selected studies on the subject matter.

Keywords: activity; family; family roles; senior; environment of living.

\section{BIBLIOGRAFIA}

Adamski, F., Rodzina, w: Encyklopedia pedagogiczna XXI wieku, t. 5, red. T. Pilch, Warszawa 2006, s. 306-311.

Adamski, F., Rodzina. Wymiar społeczno-kulturowy, Kraków 2002.

${ }^{61}$ L. Dyczewski, Ludzie starzy i starość w społeczeństwie i kulturze, Lublin 1994, s. 59. 
Adamski, F., Socjologia małżeństwa i rodziny. Wprowadzenie, Warszawa 1984.

Biernat, T., O przemianach definiowania rodziny i ich konsekwencjach, „Społeczeństwo i Rodzina" 18 (2009) 1, s. 28-39.

Bołoz, W., Przemiany rodziny we współczesnym społeczeństwie, „Homo Dei” 78 (2009) 1, s. $11-21$.

Brzezińska, M., Proaktywna starość. Strategie radzenia sobie ze stresem w okresie późnej dorosłości, Warszawa 2011.

Chabior, A., Życie rodzinne i funkcjonowanie gospodarstwa domowego, w: Ludzka starość. Wybrane zagadnienia gerontologii społecznej, A. Fabiś, J.K. Wawrzyniak, A. Chabior, Kraków 2015, s. 134-148.

Chabior, A., Wawrzyniak J.K., Marginalizacja i dyskryminacja osób w okresie późnej dorosłości, w: Ludzka starość. Wybrane zagadnienia gerontologii społecznej, A. Fabiś, J.K. Wawrzyniak, A. Chabior, Kraków 2015, s. 241-257.

Czekanowski, P., Rodzina $w$ życiu osób starszych i osoby starsze $w$ rodzinie, w: Polska starość, red. B. Synak, Gdańsk 2002, s. 140-172.

Dudek, M., Funkcje rodziny, w: Leksykon pedagogiki rodziny, red. J. Kułaczkowski, Warszawa 2011, s. 58-60.

Dyczewski, L., Ludzie starzy i starość w społeczeństwie i kulturze, Lublin 1994.

Dyczewski, L., Rodzina, społeczeństwo, państwo, Lublin 1994.

Dyczewski, L., Rodzina twórca i przekazicielem kultury, Lublin 2003.

Dzięgielewska, M., Człowiek stary a rodzina, w: Podstawy gerontologii społecznej, B. Szatur-Jaworska, P. Błędowski, M. Dzięgielewska, Warszawa 2006, s. 87-112.

Halicki, J., Relacje międzygeneracyjne jako jeden z elementów poszerzających przestrzeń życiowa ludzi starszych, w: Przestrzeń życiowa i społeczna ludzi starszych, red. M. Dzięgielewska, Łódź 2000, s. 275-280.

Konieczna-Woźniak, R., Zaangażowanie ludzi starszych w przekaz międzypokoleniowy, w: Dorosłość wobec starości. Oczekiwania. Radości. Dylematy, red. R. Konieczna-Woźniak, Poznań 2008, s. 305-313.

Kwak, A., Rodzina - formy i warunki funkcjonowania, w: Encyklopedia pedagogiczna XXI wieku, t. 5, red. T. Pilch, Warszawa 2006, s. 311-321.

Kwak, A., Rodzina jako środowisko wychowawcze, w: Pedagogika społeczna. Człowiek $w$ zmieniającym się świecie, red. T. Pilch, I. Lepalczyk, Warszawa 1993, s. 121-144.

Leszczyńska-Rejchert, A., Człowiek starszy i jego wspomaganie - w strone pedagogiki starości, Olsztyn 2010.

Majkowski, W., Funkcje, w: Słownik małżeństwa i rodziny, red. E. Ozorowski, Warszawa-Łomianki 1999, s. 391-392.

Misiak, W., Rola społeczna, w: Elementarne pojęcia pedagogiki społecznej i pracy socjalnej, red. D. Lalak, T. Pilch, Warszawa 1999, s. 247-248.

Miszczak, E., Funkcjonowanie rodziny $z$ osoba $w$ wieku sędziwym, w: Rodzina polska. Wybrane aspekty funkcjonowania, red. M. Szyszka, Lublin 2013, s. 79-95.

Orzechowska, G., Aktualne problemy gerontologii społecznej, Olsztyn 1999.

Pacholski, M., Słaboń A., Słownik pojęć socjologicznych, Kraków 2010. 
Pikuła, N., Etos starości w aspekcie społecznym. Gerontologia dla pracowników socjalnych, Kraków 2011.

Różański, T., Z problematyki przemian i zagrożeń współczesnej rodziny, „Teologia i Człowiek" 32 (2015) 4, s. 129-141.

Segiet, K., Miejsce człowieka starego w codzienności rodzinnej, w: Starość w perspektywie studiów pedagogicznych, red. A. Tokaj, Leszno 2008, s. 56-68.

Skibińska, E.M., Mikroświaty kobiet. Relacje autobiograficzne, Warszawa 2006.

Slany, K., Alternatywne formy życia małżeńsko-rodzinnego w ponowoczesnym świecie, Kraków 2002.

Smoląg, S., Funkcjonowanie starszych pokoleń $w \dot{z} y c i u$ rodzinnym i społecznym, w: Oblicza starości we współczesnym świecie. Perspektywa społeczno-kulturowa, t. 2, red. M. Guzewicz, S. Steuden, P. Brudek, Lublin 2015, s. 85-97.

Steuden, S., Psychologia starzenia się i starości, Warszawa 2011.

Straś-Romanowska, M., Późna dorosłość. Wiek starzenia się, w: Psychologia rozwoju człowieka. Charakterystyka okresów życia człowieka, red. B. Harwas-Napierała, J. Trempała, Warszawa 2005, s. 263-292.

Szarota, Z., Starzenie się i starość w wymiarze instytucjonalnego wsparcia na przykładzie Krakowa, Kraków 2010.

Szatur-Jaworska, B., Życie rodzinne ludzi starych w Polsce, „Polityka Społeczna” 26 (1999) 9, s. 17-19.

Szlendak, T., Socjologia rodziny. Ewolucja, historia, zróżnicowanie, Warszawa 2010.

Tokaj, A., Rodzina w życiu seniora a przebieg procesu jego adaptacji do starości, w: Seniorzy $w$ rodzinie, instytucji i społeczeństwie. Wybrane zagadnienia współczesnej gerontologii, red. A. Fabiś, Sosnowiec 2005, s. 41-49.

Trafiałek, E., Polska starość $w$ dobie przemian, Katowice 2003.

Trafiałek, E., Starość w Polsce, w: Zagrożenia człowieka i idei sprawiedliwości społecznej, t. 1, red. T. Pilch, T. Sosnowski, Warszawa 2013, s. 187-201.

Trafiałek, E., Wykluczenie społeczne ludzi starszych. Źródła, skutki, perspektywy na przyszłość, w: Starość i starzenie się jako doświadczenie jednostek i zbiorowości ludzkich, red. J.T. Kowaleski, P. Szukalski, Łódź 2006, s. 171-176.

Tyszka, Z., Struktura i funkcje rodziny oraz świadomość rodzinna, w: Podstawowe pojęcia i zagadnienia socjologii rodziny, Z. Tyszka, A. Wachowiak, Poznań 1997, s. 43-60.

Tyszka, Z., Z metodologii badań socjologicznych nad rodziną, Poznań 1991.

Wysocka, E., Człowiek a środowisko życia. Podstawy teoretyczno-metodologiczne diagnozy, Warszawa 2006.

Zrałek, M., Społeczne konteksty starzenia się w Polsce, w: Starość w Polsce. Aspekty społeczne i edukacyjne, A. Fabiś, M. Muszyński, Ł. Tomczyk, M. Zrałek, Oświęcim. 2014, s. 9-50. 